\title{
THE IMAGE OF THE GERMAN, THE POLE, THE LATVIAN, AND THE LITHUANIAN IN LITHUANIAN AND LATVIAN FOLKLORE
}

\author{
Laima Anglickiené \\ Associate Professor of Cultural Studies \\ Vytautas Magnus University, Kaunas, Lithuania \\ laimute.anglickiene@vdu.lt
}

Antra Klavinska

Senior Research Fellow

Research Institute for Regional Studies

Rezekne Academy of Technologies, Latvia

antra.klavinska@rta.lv

\begin{abstract}
In multi-ethnic societies, one way in which ethnicity manifests itself is in classifying people according to their ethnic origin. Such classification is based on stereotyping and is typically achieved by emphasizing certain common characteristics rather than individual particularities. Both lived experience and folklore corroborate the fact that ethnic stereotypes, ethnic self-awareness, and identity are also influenced by historical circumstances. This article focuses on Lithuanians' and Latvians' attitudes towards Poles and Germans, and towards one another during the period between the eighteenth and the first half of the twentieth centuries. The aim of this article is to reveal how the folklore of the two neighbouring nations, Lithuanians and Latvians, depicts the aforementioned ethnic groups; what historical events, cultural and social factors determined the similarities and differences in their portrayal in Lithuanian and Latvian folklore.
\end{abstract}

Keywords: folklore, folk songs, Germans, Latvians, Lithuanians, paroemias, Poles

\section{APPROACHES, METHODS, AND MEASURES}

Neighbouring nations are usually characterized by numerous cultural similarities, but also differences in their lifestyle, customs, behaviour, and appearance. They do not go unnoticed and often give impulse to the creation of ethnic stereotypes. Lithuania and Latvia are two neighbouring countries with the same 
ethnic minority groups living in their territories. Because of the shared historical circumstances, the two nations also share quite similar attitudes towards one or another ethnic group. This article discusses the attitudes Lithuanians and Latvians have towards Poles, Germans, and towards each other. The aim of this article is to discuss how Lithuanian and Latvian folklore portrays the same ethnic groups and what historical events as well as cultural and social factors determined the similarities and/or differences in their portrayal.

Folklore can be seen as a way of communicating experiences as it helps see which events, social phenomena and relations as well as character features are regarded as significant in the collective consciousness of one or another nation. Folklore also makes use of and often reinforces stereotypes about other nations. As noted by Thomas Hylland Eriksen:

Stereotypes are simplistic descriptions of cultural traits in other groups which are conventionally believed to exist. ... Ethnic stereotypes are often morally condemning ..., and such images of others may strengthen group cohesion, boundaries and one's self-perception. In polyethnic societies, people also commonly hold stereotypes about themselves; ... tend to describe themselves collectively as honest, generous folk in implicit contrast to other ethnic groups. It is impossible to make a general statement about the relationship of stereotypes to 'facts'. They can be exaggerated, overly generalising and ideologically charged descriptions of social facts. (Eriksen 2001: 264)

The material for this research was collected at the main Lithuanian and Latvian folklore archives (LTR, LFK), which have been collecting items of folklore since the beginning of the twentieth century; from electronic databases of genre-specific texts and major song collections; and from the folklore collections published in Lithuanian and Latvian during the twentieth century. The number of Lithuanian and Latvian folklore texts which mention people of other ethnic groups is very high; therefore, the scope of the present research had to be limited and includes only songs, paroemias (proverbs and sayings), and humorous tales, most of which had been recorded before the middle of the twentieth century and thus reflect the situation during the period between the eighteenth and the middle of the twentieth centuries. These folk genres feature characters of other ethnicities more frequently than others. Folk songs differ from other genres of folklore when it comes to ethnonyms of ancient origin and specific stylistic features; diversity and polychronism in the usage of ethnonymic lexicon. Historical and war songs, wedding songs, and humorous songs mention people of other ethnicities with particular frequency. Paroemias, often through 
their comparative structures, use ethnonyms not only to describe foreigners, but also to emphasize their otherness, singling out certain strange and, therefore, negative features of these people that usually live close by. Humorous folktales talk about people's everyday troubles and joys and bring the listener closer to the real-life conditions of the period during which they were created. These folktales are often similar to anecdotes, short witty stories about some misunderstanding or how someone has made fun of themselves. Assuming the point of view of a humble Lithuanian or Latvian peasant, the two narrative genres most often ridicule foreigners as representatives of higher social layers, including the nobility, who also often belong to different religious confessions. However, the present article does not analyse more recent anecdotes, which have become particularly popular lately, for example, those portraying the relationship between Poles and Germans in the twenty-first century (Anglickienè 2011).

The most important studies focusing on the image of foreigners in Lithuanian and Latvian folklore are Latvian folklorist Jānis Rozenbergs's collection of essays titled Tautas un zemes latviešu tautasdziesmās (People and Lands in Latvian Folk Songs) (2005) and Lithuanian ethnologist Laima Anglickienè's monograph titled Kitataučiu ivvaizdis lietuviu folklore (The Image of Foreigners in Lithuanian Folklore) (2006). The novelty of this article is an analysis of ethnonyms in folklore texts, conducted by using semantic structure models as proposed by cognitive and anthropological linguistics, which emphasize the historical context and comparative aspects in the construction of the image of foreigners.

\section{Semantic structure}

The model of the semantic structure of ethnonyms used in this article is grounded upon models of semantic structure developed in cognitive linguistics and anthropological linguistics, which have much in common. For example, both in cognitive linguistics (Geeraerts \& Cuyckens 2007) and in contemporary Slavic ethno-linguistics (Bartmiński \& Zinken 2009; Berezovich \& Gulik 2002; Tolstaia 2006), one of the central terms is concept. The school of Russian cognitive semantics identifies the following structure of the concept: 1 ) the image (perceptive, i.e., traits perceptible with senses and cognitive traits; metaphorical understanding of objects or phenomena); 2) informative content - the minimum of cognitive traits determining the nature of the concept, i.e., definition of the concept's keyword; 3) interpretive field (evaluative, utilitarian, socio-cultural, paremiological area) (Popova \& Sternin 2007: 104-115). These structural principles are used in this article to elaborate on the model of ethnonym semantics. 
Russian ethno-linguists propose a method of describing the connotational semantics of ethnonyms, called onomasiological portrait (Berezovich \& Gulik 2002). Berezovich and Gulik examine the contrastive aspect, which is important in cognitive and anthropological linguistics, and also offer the following criteria to structure a comparative analysis: 1) 'objective' descriptors, i.e., the idea of the emergence of an ethnic group (folk etymology), language characteristics, place of residence, biological characteristics (appearance, physical capacities, sexual sphere, etc.), mentality (character traits, intelligence, habits, religiousness), and social characteristics (economic sphere, relations with others, impact on other cultures); 2) 'subjective' descriptors, i.e., emotional evaluative characteristics (mostly negative, in the sense of 'incomprehensible', 'wrong', 'false') (Berezovich \& Gulik 2002: 59). This theoretical approach was further developed and elaborated upon in the doctoral thesis by Antra Kḷavinska, Etnonimi latgaliešu folklorā: lingvistiskais aspekts (Ethnonyms in Latgalian Folklore: Linguistic Aspect), where she analysed ethnonymic lexicon in Latgalian (the Latvians of Latgale region) folklore and addressed the problems and opportunities related to the lexical identification of ethnonyms, as well as to their typological and semantic determination (Klavinska 2015b).

This article builds the image of foreigners using the following structure:

1) nominative field - ethnonyms used for the designation of ethnos;

2) interpretive field (evaluating attitude), within which we can distinguish:

- religious field: religious / confessional affiliation;

- cultural field: customs and traditions;

- social field: occupation, place of living;

- linguistic field: language, communication abilities, and need;

- perceptive field: physical appearance, paralinguistic traits;

- the field of emotional and intellectual evaluation.

\section{HISTORICAL CONTEXT AND ETHNIC SITUATION IN LITHUANIA AND LATVIA}

First of all, the historical circumstances in Lithuania and Latvia that influenced the representation of different ethnic groups both in real life and in folklore should be described. Poles and Germans have lived both in Lithuania and Latvia for a very long time; moreover, until the end of the nineteenth century, when the Lithuanian and Latvian national revival movements were established, both Poles and Germans occupied higher positions than local Lithuanians and Latvians in the social hierarchy of both countries. 


\section{Historical situation and ethnocultural diversity in Lithuania}

In the thirteenth century, Lithuania began to unite neighbouring lands, and, in the fourteenth century, the Grand Duchy of Lithuania became the largest country in Europe. With the Lublin Union of 1569, Lithuania and Poland formed a two-state union, the Polish-Lithuanian Commonwealth. In the Union, the larger and stronger Poland occupied a superior position and, eventually, Polonization affected all aspects of life in Lithuania: politics, language, culture, and national identity. As a result, in the nineteenth century, the Lithuanian nobility already spoke Polish; Polish culture became dominant and was considered prestigious, which, consequently, could guarantee a higher social status, whereas the Lithuanian language and culture were considered to be inferior and were associated almost exclusively with peasants' way of living. During that period, the words Pole and Polish defined not only nationality or religion ${ }^{1}$ but also people of higher status, the nobility. This started changing only at the end of the nineteenth century, when the Lithuanian National Revival began, and the Lithuanian language and culture became important for the formation of Lithuanian ethnicity, leading to the creation of an independent state in the year 1918.

The Polish minority in Lithuania was formed from different waves of migration. Most Poles lived and continue living in the southeast of Lithuania (Vilnius region). In the past centuries, a significant number of Poles living in Lithuania were noblemen with high social status; around a half were peasants, while the rest lived in towns and earned their living by trade and handicraft. It is also noteworthy that this ethnic group constituted the highest percentage of the nobility in Lithuania (Anglickienè 2006: 48).

A major conflict with Poland arose in the interwar period, when the capital of Lithuania, Vilnius, and the entire Vilnius region were occupied by Poland, whereby Lithuania lost that part of its territory. Poles became principal enemies of Lithuanians; even today, when any problem with local Poles (who are the largest ethnic minority group in contemporary Lithuania, see Table 1) or Poland occurs, Lithuanians recall the loss of Vilnius and do not spare negative epithets to them.

Germany and Lithuania have many-sided ties. The German state (Prussia) was Lithuania's neighbour until World War II. Many Lithuanians lived in German territories, in the historical-ethnographic region of Prussia and, later, Eastern Prussia, situated in the north-eastern parts of the province of Prussia. This territory came to be known Lithuania Minor (Lith. Mažoji Lietuva) or Prussian Lithuania (Ger. Preussisch Litauen, currently, Kaliningrad Oblast of Russia). In Lithuania, the majority of Germans lived in the south-western 
part of the country and along the borderline between the two countries. There is also a long history of hostility between the two nations: in the Middle Ages, Lithuanians were fighting off the Teutonic Order and the Livonian Brothers of the Sword, and in the twentieth century, the two nations were members of two opposing military alliances during World Wars I and II.

In Lithuania, numerous Germans earned their living by agriculture; many of them owned manors, whereas the rest were craftsmen or merchants. For this reason, Lithuanians always associated them with a higher social status. The Lutheran religion that Germans followed also distinguished them from local Lithuanians that practiced Catholicism (Anglickienè 2006: 45-46).

The majority of Latvians in Lithuania lived in the border areas. During the eighteenth and nineteenth centuries, many Lithuanians used to cross the border and work as agricultural labourers in Latvia, because Latvian farmers were richer and could pay better salaries. Another significant difference was the Lutheran religion practiced by Latvians. However, in contemporary Lithuania, Latvians are perceived as representatives of a kindred Baltic nation (the ethnic nickname braliukas, 'little brother', is used both in Lithuania and Latvia).

Table 1 shows the development of ethnocultural diversity in Lithuania during the past two centuries.

Table 1. Ethnic groups in Lithuania (\%) (Vaitiekus 1992: 12; Population 2013: 7)

\begin{tabular}{|l|l|l|l|l|l|l|l|}
\hline \multirow{2}{*}{ Nationality } & \multicolumn{7}{l}{ Year } \\
\cline { 2 - 8 } & $\mathbf{1 8 5 7}$ & $\mathbf{1 8 9 7}$ & $\mathbf{1 9 2 3}$ & $\mathbf{1 9 5 9}$ & $\mathbf{1 9 8 9}$ & $\mathbf{2 0 0 1}$ & $\mathbf{2 0 1 1}$ \\
\hline Lithuanians & 75.6 & 61.6 & 69.2 & 79.3 & 79.6 & 83.45 & 84.2 \\
\hline Russians & 1.4 & 4.8 & 2.5 & 8.5 & 9.4 & 6.31 & 5.8 \\
\hline Poles & 5.6 & 9.7 & 15.3 & 8.5 & 7.0 & 6.74 & 6.6 \\
\hline Byelorussians & 0.3 & 4.7 & 0.4 & 1.1 & 1.7 & 1.23 & 1.2 \\
\hline Jews & 10.7 & 13.1 & 8.3 & 0.9 & 0.3 & 0.12 & 0.1 \\
\hline Latvians & 1.0 & 1.3 & 0.6 & 0.2 & 0.1 & 0.08 & 0.07 \\
\hline Germans & 5.1 & 4.4 & 3.4 & 0.4 & 0.1 & 0.09 & 0.08 \\
\hline Others & 0.3 & 0.4 & 0.3 & 1.0 & 1.6 & 2.0 & 1.95 \\
\hline
\end{tabular}

\section{Historical situation and ethnocultural diversity in Latvia}

The first ethnic groups to inhabit the territory of present-day Latvia - the Baltic Finns and the Balts - established contacts with other ethnic communities at different times: Russians (10th-11th c.), Germans (12th-13th c.), the Roma (15th16th c.), Poles (16th c.), Jews (16th c.), Swedes (16th c.), etc. (Apine \& Dribins 1998). 
The arrival of other ethnic communities into the territory of Latvia was determined by various circumstances and reasons: conquering new lands, forced migration, worsening economic or social conditions in their ethnic or previous homelands, searching for new opportunities, etc. Over time, the numerical proportion and social roles of the founding nation (Latvians) and other ethnic groups changed (Boldāne 2011: 68).

The arrival of Germans and their permanent settlement in the territory inhabited by the ancient Latvian tribes and the Livs took place in the twelfth and thirteenth centuries, during the Crusades, and was related to the spread of the Christian faith. The efforts of German traders to establish transit routes and local sales warehouses in the territory of Latvia played a significant role, too. German conquerors and their descendants introduced feudal relations in Latvia, and, in consequence, the Livonian German nobility emerged, who gradually became landowners and built their castles and manor houses (Dribins 2007: 141). These developments are depicted in Latvian folklore, especially in the tales and legends about castle mounds, castles, and manors, and in folk songs that describe relationships with the nobility and life at the manor.

After Russia's annexation of three regions of Latvia - Latgale (1772), Kurzeme and Zemgale (1795) - a German national minority group formed, united by mutual interests. At the beginning of the nineteenth century, they called themselves the Balts, but in the second half of the century identified themselves as the Baltic Germans (Ger. Deutschbalten, Baltische Deutschen) (Dribins 2007: 147).

Up to 1939, Germans were the third largest, and in the interwar period, along with the Jews, one of the two economically most influential ethnic minority groups in Latvia. However, after World War II, only a very small number of Germans remained in the country (Boldāne 2011: 154).

Historically, Latvians did not have deep and persistent contacts with the Polish nation and its culture; in different regions of Latvia, historical and cultural contacts were of different nature and importance. The Livonian War (1558-1583) led to the break-up of the Livonian Confederation; the territory of Latvia ended up under various levels of Polish (from 1569, Polish-Lithuanian) influence or direct rule. The Polish influence was the most noticeable in the territory of Latgale, which was incorporated into the Polish-Lithuanian Commonwealth and in which Poles became the political majority; under the influence of the Polish élite, local German nobility was Polonized (Durejko 1995: 126). Polish influence remained strong even after the annexation of this territory by the Russian Empire in 1772. Just like Germans in other regions of Latvia, Poles introduced their own customs in Latgale. In Latgalian folklore, they are primarily associated with the nobility and the Catholic clergy. Both German 
and Polish political élites introduced numerous cultural differences (in religion, language, education, architecture, art, social life) between the Latvians of Latgale and the Latvians living in other regions of the country.

In the second half of the nineteenth century, economic development and political events affected the social status and territorial distribution of Poles in Latvia. Even though the highest concentration of Poles remained limited to Latgale, their proportion increased in the cities and other areas in Latvia (Dribins 2007: 162). This also affected their choice of activity: agriculture, manufacturing, transportation, and communications. During the interwar period, a new professionally defined ethnic group emerged in Latvia, namely, Polish (also Lithuanian) farmers and seasonal workers on the largest farms (Boldāne 2011: 139).

In contemporary Latvia, Lithuanians are perceived as representatives of a kindred Baltic nation (the ethnic nickname bralukas 'little brother'), as a neighbouring nation, and as an ethnic minority. However, the long-term influence of different nations and cultures (Latvians were influenced by Germans, while Lithuanians - by Poles) and adherence to different Christian denominations (Latvians being Protestants, and Lithuanians - Catholics) have resulted in differences in mentality and the perception of the world (Boldāne 2011: 126). The Latvians of Latgale are an exception; since the territories of Latgale and Lithuania were united in the past, this resulted in certain shared features, for instance, the Catholic faith, conservative economic approaches, or the low level of education among farmers. Ethnic contacts between Latvians and Lithuanians are most prominently depicted in folklore texts recorded in the ethnic borderlands. Up to the present day, Lithuanians mainly live in the borderlands and in the largest cities of Latvia.

The census data (see Table 2) provides a rather precise record of the ethnic situation in Latvia from the end of the nineteenth century to the present day.

Table 2. Ethnic groups in Latvia (\%) (Central Statistics)

\begin{tabular}{|l|l|l|l|l|l|l|l|}
\hline \multirow{2}{*}{ Nationality } & \multicolumn{7}{|l}{ Year } \\
\cline { 2 - 8 } & $\mathbf{1 8 9 7}$ & $\mathbf{1 9 2 5}$ & $\mathbf{1 9 3 5}$ & $\mathbf{1 9 5 9}$ & $\mathbf{1 9 8 9}$ & $\mathbf{2 0 0 0}$ & $\mathbf{2 0 1 1}$ \\
\hline Latvians & 68.3 & 73.4 & 76.9 & 62.0 & 52.0 & 57.7 & 62.1 \\
\hline Russians & 12.0 & 10.5 & 8.8 & 26.6 & 34.0 & 29.6 & 26.9 \\
\hline Byelorussians & No data & 2.1 & 1.4 & 2.9 & 4.5 & 4.1 & 3.3 \\
\hline Poles & 3.4 & 2.8 & 2.6 & 2.9 & 2.3 & 2.5 & 2.2 \\
\hline Lithuanians & No data & 1.3 & 1.2 & 1.5 & 1.3 & 1.4 & 1.2 \\
\hline Jews & 7.4 & 5.2 & 4.9 & 1.8 & 0.9 & 0.4 & 0.3 \\
\hline Germans & 6.2 & 3.8 & 3.3 & 0.1 & 0.1 & 0.1 & 0.1 \\
\hline Estonians & - & 0.4 & 0.4 & 0.2 & 0.1 & 0.1 & 0.1 \\
\hline Others & 2.7 & 0.6 & 0.5 & 2 & 4.8 & 4.1 & 3.8 \\
\hline
\end{tabular}




\section{NOMINATIVE FIELD: ETHNONYMS IN FOLKLORE TEXTS}

In the Lithuanian and Latvian languages and folklore, ethnic groups that this article focuses on are called in many different ways; derived from different languages, these names were created and used over different periods of time.

In the Baltic languages, the exoethnonym ${ }^{2}$ vācieši (Latvian) or vokiečiai (Lithuanian) is nowadays used to designate Germans. However, in Lithuanian folklore, other names can also be found: prūsai, preisai 'Prussians', germanai 'Germans', and, specifically after World War II, fricai 'Fritz', naciai 'Nazis', niemcai 'Germans' (from Russian nemcy), hitlerininkai 'Hitler's accomplices'. The label kryžiuočiai 'Crusaders' is also applied to Germans, even though it is rare and probably appeared quite late, under the influence of literature, seeking to add a certain historical component to literary texts (Anglickiene 2006: 185). In Lithuania, the word 'Prussian' has a geographical (= an inhabitant of Prussia and Lithuania Minor), national (= German), and religious (= Lutheran, Protestant) meaning. Notably, this ethnonym was frequently used to refer not only to the Lutherans of Prussia, but also to the followers of the Protestant faith in general (Slavenniene 1991: 31), i.e., including the Lithuanians practicing Protestantism. Different names were sometimes applied synonymously; for example, a single song can mention both Germans and Prussians.

In Latvian folklore, Germans are referred to with an older form of the ethnonym vāci, the compound vāczemnieki 'inhabitants of Germany', and the latest denomination vācieši, as well as collocations griķu, putru, kārklu or skalu vācietis 'buckwheat, porridge, osier or sliver German', meaning 'that [Latvian] who unsuccessfully pretends to be German' (Mīlenbahs 1932: 490-492); on the other hand, the denomination pusvācietis 'half-German' found in folk songs, is explained by dictionaries as referring to 'a person who has one German parent', 'a Latvian (usually rich) who tries to be similar to Germans' (Grabis 1987: 477). Latvian folklorist J. Rozenbergs has observed that in Latvian folklore, ethnonyms vāci and vācieši are used to designate not so much the inhabitants of Germany but rather the Baltic German nobility of Latvia (Rozenbergs 2005: 23). The ethnonym prūši 'Prussians' is also mentioned in Latvian folklore. Having analysed the semantics of this lexeme in classical Latvian folk songs, Rozenbergs concludes that it is used to name both ancient Prussians of the Baltic descent and the inhabitants of German Prussia, i.e., Germans (Rozenbergs 2005: 46). In Latgalian folklore, the following designations of Germans have been found (phonetic variants): vuoci, vuocīši, vuoczemnīši, pusvuocīts, pruši, brūži (Klavinska 2015b: 154).

In modern Baltic languages, two different denominations designate Poles: in Lithuanian lenkai, possibly borrowed from the Belarusian lęchı 'Pole' 
(Merlingen 1978: 72), and in Latvian poli, supposedly borrowed from the Middle Low German pōl 'Pole' (Karulis 2001 [1992]: 707).

In Lithuanian folklore, especially older songs, Poles are also referred to as paliokai, which is an autonym of the Slavic origin (Pol. 'Polak').

In Latvian folklore, the ethnonym most frequently used to refer to Poles is pol,i, also diminutives (singular) polits, polenin, š, compound apalpoli 'round Poles'. In war, engagement, and wedding songs, ethnonyms polı i and leiši ('Poles' and 'Lithuanians') are usually placed next to each other and are used to mean 'foreigners, aliens' (Rozenbergs 2005: 86-87). In Latgalian folklore, lexemes pūli, polaki are used to name Poles (Kḷavinska 2015b: 144-145).

In Latvian historical sources and language, three variants for designating Lithuanians are found: with the root liet- (Lithuanian tradition), with the root lit- (Slavic tradition), and leit- (Latvian tradition). The primary source for all the three variants is considered to be the Lithuanian form *Lietuva $<*$ Lêtuv $\bar{a}$ (Zinkevičius 2005: 185). In Latvian folklore, the most ancient ethnonym used for naming Lithuanians is leiši. Other designations for Lithuanians have been found in the texts recorded in Latgale: lītuvīši, leitovīši, lìtaunīki, litvaki (Kḷavinska 2015b: 159).

Ethnonyms naming Latvians are latvieši, the poetic form latuji (in Latvian), and latviai (in Lithuanian).

In Lithuanian folklore, Latvians do not have any other names, but in dialects a different syllable can be stressed. In standard Lithuanian, the first syllable is stressed - lãtviai 'Latvians' (singular lãtvis) - whereas in folklore texts, the

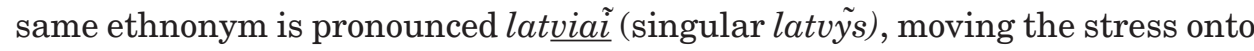
the second syllable.

The same ethnonym can also bear different meanings in different nations. For example, Latvians use the word leišiai (i.e. 'Lithuanians') to call the Latvians of Lithuania, and Lithuanians around Akmenè (a Lithuanian town near the Lithuanian-Latvian border) also use the same ethnonym to refer to the local Latvians (Butkus 1995: 210), but in folk songs recorded in Vidzeme, the Latvians of Latgale tend to be designated by the ethnonyms polı 'Poles,' and leiši 'Lithuanians', which acknowledge not ethnic but rather territorial belonging to the Polish-Lithuanian Commonwealth (Rozenbergs 2005: 67).

\section{INTERPRETIVE FIELD. THE IMAGE OF DIFFERENT ETHNIC GROUPS: LATVIAN AND LITHUANIAN EXAMPLES}

The following section discusses how representatives of different nations are traditionally described in Lithuanian and Latvian folklore. 
Lithuanian and Latvian folklore reflects two different sides of communication with Germans: hostility and peaceful neighbourhood. For this reason, the image of the German is also two-sided: the German can be pictured as a conqueror but also as a local nobleman or an artisan. However, a closer look at many folklore texts reveals a prevalent disdainful attitude towards this nation. It can be observed that in Latvian and Lithuanian folklore, negative attitude towards Germans is expressed both in the times of peace and in the times of war: Germans are referred to as belonging to another (higher) social stratum and criticized for their bad attitude to the native (local) population, often through comparisons to the devil. In folklore, Germans usually have features of the stereotypical 'stranger'. For example, folk jokes mock Germans' stupidity as well as negative features and habits of the German nobility, such as greed, cruelty, arrogance, laziness, cowardice, adventurism, passion for alcohol, seductive behaviour with local (Latvian) girls and married women, etc.

In narrative folklore, Germans, unlike other foreigners, such as Jews or the Roma, who can sometimes be deceived but more often deceive others, are always pictured as stupid. It can be explained by the fact that Germans were often enemies not only to Lithuanians and Latvians but also to many other nations. As Slovak researcher Gabriela Kiliánová notes, in folklore of many different nations, the image of the German is related to the image of the enemy: it is often characterized by power, cruelty, maliciousness, brutality, but also stupidity and ignorance (Kiliánová 1994: 110). In 1938, Lithuanian folklorist Jonas Balys noticed that in such languages as French, Italian, and Danish, the words used to refer to Germans also mean 'stupid', whereas in Bosnia such words mean 'an insidious person' (Balys 1938a: 516). This shows that Lithuanians and Latvians share an attitude to Germans that is similar to that of many other European nations.

In Lithuanian folklore, when Poles are mentioned, several themes dominate. Folk songs mention historical events: struggles of Lithuanians and Poles against common enemies in the seventeenth-nineteenth centuries and struggles against each other for the Vilnius region in the interwar period of the twentieth century, when Lithuanians and Poles became irreconcilable enemies. Other texts portray the Pole as a nobleman in a rather controversial manner, both positively and negatively. The Polish language and character traits often become an object of mockery as well (Anglickienè 2011).

In Latvian folklore, due to different historical circumstances, Poles are never depicted as allies. In war-related folk songs, in which Poles are usually portrayed alongside Lithuanians, their image is generalized to that of enemies. However, in the depiction of Poles, two tendencies can be observed: hostility in the representations of military and social relationships, and friendly attitudes in 
engagement- and wedding-related folk songs. In folk texts recorded in Latgale, the image of the Pole is very prominent, and Poles are described as boastful, arrogant, and harsh noblemen, or sometimes poor because they have lost their wealth by gambling and leading dissolute lives.

Lithuanian folklore texts that refer to Latvians are known only in a relatively small area, mainly along the borderline, where most of the Latvian minority in Lithuania lived. Latvians are often portrayed as sorcerers. Different folk stories also tell about funny misunderstandings that occur due to the (mis)use of languages or religious/confessional (Catholics vs. Protestants) differences. It is also notable that Lithuanian folklore often portrays Latvians as richer than Lithuanians.

Lithuanians in Latvian folklore are represented as a neighbouring nation, similar to Poles and Russians. Their image is often generalized to depict the Lithuanian as a conqueror of Latvian lands; however, Lithuanians are also portrayed as potential marriage partners, sometimes desirable, but sometimes not. Another tendency is to foreground language use, as the languages the two nations speak are quite similar. Latvian folklore also depicts funny misunderstandings that occur due to the different meanings of similar words. Lithuanians are also portrayed as poorer and more foolish than Latvians.

The next section of the article goes on to focus on how Poles, Germans, Lithuanians, and Latvians are represented in the interpretive field of Lithuanian and Latvian folklore, where folklore examples of both nations repeat the same semes and where differences arise.

\section{Religious field}

Poles, Lithuanians, and Latgalians are Catholic; therefore, there are no folklore texts describing any religious disagreements or misunderstandings between them, while followers of other religions are often mocked and ridiculed. Lithuanian folklore reflects only certain disagreements between Catholic Poles and Lithuanians, mostly of historical-political character; for instance, during the nineteenth through to the mid-twentieth centuries, conflicts would sometimes arise in Lithuania because of the language of the church service, especially in multicultural and multilingual Catholic parishes, where people of different nationalities lived. Language-based conflicts became especially frequent in the Vilnius region during the interwar period, when the Lithuanian language was prohibited in the multi-ethnic parishes occupied by Poland. This induced people to speak about the injustices in the form of songs. For instance, when the relations between Lithuanian and Polish Catholics deteriorated in the parish of 
Rodūnė after the church service in Lithuanian was prohibited, which quickly provoked hostility and fights, songs called "The troubles of Rodūnè" were created and became popular among the community members of the Lithuanian origin. The plots of these songs narrate specific situations and refer to Poles as offenders of Lithuanians (Ivanauskaitè 2004: 40).

In Latvian folklore, the religious aspect is not strongly emphasized. The primary object of mockery is exaggerated religiousness attributed to Catholic Poles and Lithuanians, as can be seen in the saying "Holy as a Lithuanian girl" (LSDF 17 19289) and in the following song: "I will not marry a Pole / And my sister will not marry one / A Pole says: / Catholicism is my love (darling)!" (LFK 1602, 4510). Other texts suggest that foreigners (Lithuanians) do not know how to pray correctly: "Foreign people cannot / Say prayers; / Like Lithuanian paupers / They mumble" (DS 19171-0).

As Germans and Latvians are predominantly Protestant, there are no indications of religious differences between these ethnic groups in Latvian. It is noteworthy that in Latgalian folklore Germans are not portrayed as representatives of a foreign religion either, possibly because during so-called Polish times the German nobility converted to Catholicism. Nonetheless, Latvian folklore often mocks German priests by depicting various misunderstandings during religious rituals, which arise due to insufficient command of the Latvian language.

As may be predicted, Lithuanian folklore depicts differences between the Catholic and Protestant confessions, namely, different liturgical actions, customs, and religious festivals. For instance, in one Lithuanian folk story, a well-dressed German woman enters a Catholic church, thinks that, during the Mass, all people stand up in her honour, and says, "Do not stand up, I am not a lady of such high importance" (Slančiauskas 1975: 115).

Some Lithuanian proverbs also reflect confessional differences: "You don't confess. Are you some kind of Prussian?" (LTR 346/223); "He does not cross himself as if he were some Prussian" (LTR 346/226). Some proverbs mock Lutheran pastors: "He moves his legs apart as a Prussian protestant" (LTR 346/218); "He talks drivel like a Prussian pastor" (LTR 5224/19/46). Even the Prussian god is mocked for being different: "He was so beautiful, distorted like the Prussian god" (LKZ 1976: 501); "Smiling as the Prussian Jesus in front of the moon" (LTR 5311/994). One etiological legend describes the circumstances that gave rise to the birth of Protestantism as a different confession: one young girl agrees to marry the devil and gives birth to a son, Martin (Luther), who later distorts the Christian faith (LTR 1542/395). Another legend also mentions that the Lutheran faith is an invention of the devil (Basanavičius 1928 [1903]: 312). 


\section{Cultural field}

Lithuanian and Latvian folk songs can depict Poles as potential spouses, either desirable or not. In the latter case, cultural, social, and linguistic fields intertwine because the reasons why the spouse (Pole, German, Lithuanian or Latvian) is undesirable differ; not only different traditions but also social status, religion, and language are considered. Such songs portray different situations based on various oppositions: a warrior versus a ploughman, a nobleman versus a peasant. Any of the characters mentioned in the opposition may become the hero in a song. In Lithuanian songs of matchmaking, the image of the Pole is especially controversial. For example, a young girl does not want to marry a Pole, and thus the song highlights his negative traits, such as speaking a different language and occupying a different social status: "Oh you Poles, / So immoral, / You won't get the Lithuanian girl / Even if you pay in thalers" (Balys 1938b: 313); "I won't marry a young gentleman / I won't learn the Polish language, / I won't learn the Polish language, / I won't wish to become the mistress of the house" (Žemaitienè 1953: 60).

Latvian engagement songs also reveal an ambivalent attitude to Poles and Germans as potential spouses. There are folk songs in which a Polish or a German suitor or bride is depicted as undesirable because he or she is a representative of a foreign culture and social environment: "Five Poles want to marry me, / I pray to God, I will not marry: / If a ploughman marries me though, / I will marry him singing" (LTDz III: 10538); "Oh, my hard life, / I married a German bride! / She didn't go milling in winter, / Nor to the cornfield in summer; / In winter she spun silk, / In summer she twisted it" (LTDz VII: 22460).

Generally, Lithuanian folk songs poeticize the image of a peasant ploughman, who, in a song, can be contrasted with a person from another social layer, namely, a Pole: "Oh, everybody directed their eyes / All the crowd of Poles. / Is he a gentleman, / Or is he the Polish king's son? // Oh no, he's neither a gentleman / Nor Polish king's son, / He's his father's son, / Ploughman of the field" (Juška 1954: 1143).

In Lithuanian folk songs, noblemen or people of a higher social status are sometimes identified as Poles. In the latter case, the Pole is depicted as a desirable marriage partner, for instance: "Why did you promise me / To this rogue young man, / To this drunkard. // I was good / Only for the Polish soldier / The real nobleman" (Daukantas 1983: 66).

In a similar way, Latvian folk songs also express a desire to intermarry with wealthy Poles (in Latgale) and Germans (in other regions of Latvia), which is primarily guided by pragmatic reasons: "I will not marry anyone / Until I meet mine; / Mine has come from the Polish land / On a grey horse. / Whose horse is 
dark brown, / That boy is the best" (LFK 1471, 582); "I was knitting gloves, / Thinking about a German; / The devil brought a farmhand / Wearing patched trousers" (LTDz VII: 7300). In folk songs, girls who are believed to be suitable to marry Germans are described as beautiful and rich, but also lazy.

In Latvian folk songs, the Lithuanian girl is usually portrayed as a desirable, hardworking wife: "Marry, brother, a Lithuanian girl, / She did not delay work: / Was squatting to milk cows, / Was nursing a baby over her shoulder" (LTDz IV: 12138).

Sometimes Latvian folklore depicts marriage to foreigners as a desirable event that might ensure good relationships with neighbours: "I matched my sister with a Russian, / I am marrying a Lithuanian girl. / I went to the Russian land, / I went to the Lithuanian land, / Everywhere I have sons-in-law and relatives" (LTDz II: 3844).

In Lithuanian belief legends, Latvians are often depicted as sorcerers who possess evil powers but who are also able to help others with their magic. Legends tell about harmed domestic animals: Latvian women are believed to have the power to cast an evil eye on domestic animals, take away milk from cows, while Latvian men are said to bewitch horses (Anglickienè 2006: 229).

In Lithuanian belief legends, Prussians and Germans are also said to be sorcerers. One text tries to explain this by referring to religious differences: "They all were Lutherans, not Catholics, and they knew different magic spells" (LTR 4220/56); "You can get various magic tools from a German, for example, guns with which one can shoot as many rabbits as one wishes" (LTR 2295/200). Germans are believed to be able to help both people (LTR 1690/275) and domestic animals with their magic spells (Slančiauskas 1975: 377). Therefore, it can be stated that in Lithuanian folklore, Germans more often than Latvians are represented as sorcerers who help, not harm.

It is not unusual for one nation to attribute magic powers to another, often neighbouring nation. It is based on the our own - strange dichotomy, in which all bad things and evil powers are attributed to the foreigner. This belief is universal; for example, Danes believe that Norwegians are skilled sorcerers, whereas Norwegians attribute magic powers to Finns, and the latter to the Saami; the Saami, in the meantime, believe that sorcerers live somewhere in the east, on the Kola Peninsula (Holbek 1996: 305).

\section{Social field}

Lithuanian and Latvian folklore often represents several social groups that foreigners belong to (see Table 3). 
Table 3. Social groups according to nationality

\begin{tabular}{|l|l|l|}
\hline Social group & In Lithuanian folklore & In Latvian folklore \\
\hline $\begin{array}{l}\text { Soldiers, conquerors of } \\
\text { the land }\end{array}$ & $\begin{array}{l}\text { Germans, Russians, } \\
\text { Poles, Swedes, French }\end{array}$ & $\begin{array}{l}\text { Germans, Russians, } \\
\text { Poles, Lithuanians, } \\
\text { Estonians, Swedes, } \\
\text { French }\end{array}$ \\
\hline $\begin{array}{l}\text { Masters, noblemen, } \\
\text { landowners }\end{array}$ & $\begin{array}{l}\text { Poles, Germans, } \\
\text { Latvians }\end{array}$ & Germans, Poles \\
\hline Priests & $\begin{array}{l}\text { Germans, Russians, } \\
\text { Jews }\end{array}$ & $\begin{array}{l}\text { Germans, Poles, } \\
\text { Lithuanians, Russians }\end{array}$ \\
\hline Artisans & Germans, Russians & Germans, Russians \\
\hline $\begin{array}{l}\text { Traders and keepers of } \\
\text { taverns }\end{array}$ & Jews & Jews \\
\hline
\end{tabular}

As the table indicates, Lithuanian and Latvian folklore represents different social groups in a similar manner; however, some differences can be noticed. This section of the article discusses the images of the Pole, the German, the Latvian, and the Lithuanian.

The image of the conqueror is most prominent in war-related folk songs, as well as legends and tales. As a rule, folklore usually belittles enemies, but praises and encourages its own warriors. Folk songs are extremely flexible and adaptive; different variants of the same song can depict different enemies, depending on the situation of the singer at a specific moment of time, as can be seen in a stanza of the Lithuanian war song "When we, three brothers, grow up" (type K 616):

Where will we three [brothers] ride,

Where will we travel

To a foreign country

To the land of the king. (Jokimaitienè \& Žičkienè 1995: 348)

The final lines of different variants of the song mention different countries: to the French land, to the Turkish land, to the country of Prussia, to the Moscovian land, to the Russian land, to the Lithuanian land, to Riga, to the foreign country (Jokimaitienè \& Žičkienė 1995: 368).

However, a significant number of war songs mention realia that do not allow for an easy substitution of the enemy character; this helps researchers determine the period of their creation and the nations mentioned in them. Songs sometimes tell on which side Lithuanians or Latvians fight and mention the 
enemies; sometimes specific places, battles or distinguished military men are depicted. This renders the narrated events concrete and helps the audience recognize which specific battle is mentioned in the text (Anglickiene 2006: 115). It is also noteworthy that these folk songs reflect the differences of the historical situation in Lithuania and Latvia. Since the oldest times until the declaration of independence in the year 1918, the territory of contemporary Latvia was ruled by other powers and was often attacked by its neighbours, whereas Lithuanians had their own state or the commonwealth with Poles and thus were not always the ones attacked, but also attacked other nations, including those inhabiting the territory of the present-day Latvia.

Latvian folklore often portrays Germans as conquerors. For example: "Where is your land, German man, / Where are your horses? / Why have you come to this land / To eat my hard sweat?" (LTDz X: 31876). In war-related folk songs which depict the events of the sixteenth-eighteenth centuries, Poles, together with Lithuanians, are also often subsumed under a generalized image of a foreign conqueror: "Poles, Poles, Lithuanians, Lithuanians, / Why have you come to this land? / This land has warm sun, / Your kettle heads will break" (LFK 572, 328). It is a confirmed fact that, in the Middle Ages, Polish forces indeed participated in several wars in the territory of Livonia. After the Union of Lublin (signed in 1569), Lithuanians also participated in wars as part of the armed forces of the Polish-Lithuanian Commonwealth.

Lithuanian folk songs make minor references to the crusaders' aggression. Only folk songs of literary origin, which were created at the end of the nineteenth and beginning of the twentieth centuries mention crusaders as enemies, whereas war-historical songs usually depict fights of Poles and Lithuanians against their common enemies, namely Russians, Swedes, and Frenchmen in the sixteenth-nineteenth centuries. In the twentieth century, folk songs known as Songs of the Liberation of Vilnius became popular. They describe the loss of Vilnius as a terrible disaster to the Lithuanian nation, call Lithuanians to arms, depict Poles as self-willed, and ridicule them: "Hey, young brothers, take your guns and go! / We shall be banishing Poles out of our native land" (Ivanauskaitè \& Gudaitè 1998: 110); "We are not afraid of those Poles, / We have banished them out of Lithuania. / We shall make pickets of Poles, / And shall put up fences of younger Poles" (Ivanauskaitè \& Žičkienè 2004: 367). It is also noteworthy that, in the twentieth century, many older folk songs were adapted to the historical circumstances to depict German aggression during the two world wars.

In Lithuanian folklore, Poles are often depicted as noblemen (Pol. szlachta), whereas Germans and Latvians are represented as richer landowners on whose farms Lithuanians work as hired labourers. Joke tales often portray the German 
or the Pole as a rich landowner, who becomes the victim of a swindler. Polish noblemen are also mentioned in war-historical and wedding songs. However, it is notable that in real life szlachta could also be people of Lithuanian origin who spoke Polish and had adopted Polish culture; for this reason, they were often referred to as Poles. Thus, it is the lifestyle of people of higher or lower social status that these folk songs highlight by sometimes accentuating the higher status as the desired one. For example, one etiological legend reveals the 'better' origin of Polish szlachta: if Lithuanians are made of dark rye flour, then Poles are made of white wheat flour (Balys 1940: 97, 104). Lithuanians living in the border areas saw that Latvian landowners were richer and could provide hired labourers with better nutrition; therefore, many chose to work on Latvian farms, and Lithuanian folklore reflects the situation by depicting Latvians as more successful farmers. A proverb says: "I have grown so poor that I have nothing else to do but to hire myself as a labourer on a Latvian's farm" (LTR 628/1449).

Latvian folklore prominently portrays the German and the Pole as 'foreigners', i.e., they are depicted not only as conquerors but also as ones belonging to a different social stratum (nobility, clergy, administrative and political power) and living in the city (Rīga) or on a manor. Several folk texts reveal the cruel attitude of the German and Polish nobility to Latvian serfs. Because of their cruelty, Germans are compared to the devil, and a desire to get revenge on them is expressed: "Oh, German, child of the devil, / Tomorrow you will be burned, / They will tie your hands, tie your legs, / Will put you on a steak" (LTDz X: 31861). It must be noted that in different versions of folk songs dealing with similar topics, recorded in different regions of Latvia, different ethnonyms (polis 'Pole' or vācietis 'German') are used as synonyms for the superordinate concept kungs 'master'.

In Latvian paroemias, especially in similes, the image of a poor foreigner is also revealed: "Naked as a Pole" (LSDF 527 1440); "Wailing as a Lithuanian pauper" (LSDF 877 2715); "Proud as a German pauper" (LSDF 759 619).

\section{Linguistic field}

In joke tales and anecdotes, humorous situations are often created by depicting representatives of two different nations or speakers of different dialects, who do not understand each other properly because of words or phrases that sound similar but may be understood differently in different languages or dialects. In one Lithuanian anecdote, a German enters a yard and asks a woman he meets for 'ajer' (Ger. Eier 'eggs'); she brings him a tuft of sweet-flag leaves (Lit. 'ajeras') 
(Janonis \& Janonienè 1982: 900). In communication between Latvians and Lithuanians, humour is often based on lexis with different semantics in the two Baltic languages: for instance, in Latvian, druska means 'a little', whereas in Lithuanian druska means 'salt'. In communication with foreigners living in the territory of Latvia or Lithuania, the grounds for comic misunderstandings are poor Latvian or Lithuanian language skills.

Latvian folk songs reveal a tolerant attitude towards other languages; moreover, foreign language skills are highly valued, especially when portraying social life in the borderland areas: "Living in the borderland, / I use language in three ways; / Which people propose, / That language I speak" (LTDz IV: 13224). Songs also suggest that language is not the only feature of a person's ethnic identity: "Am I a Lithuanian, / If I speak the Lithuanian language, / If I speak the Lithuanian language, / If I am wearing a Lithuanian suit?" (LTDz XI: 55989).

Humoristic folk songs collected in south-eastern Lithuania, inhabited by bilingual speakers of Lithuanian and Polish, are often based on wordplay. Different lines of the same song may be sung in different languages:

Mūs Onutè pasipūtè [Lt]

Pačy do mnie kšyvu, [Pl]

Aš Onuty pasiputy [Lt]

Zafonduja piva. [Pl]

$O$ tas alus alutèlis $[\mathrm{Lt}]$

$Z$ jienčmeniu robionas $[\mathrm{Pl}]$

Ir dèl mūsu jis linksmumo [Lt]

Mieliu doložonas. [Pl]

(VDU 1089/23)

Our Ann is so stuck-up / Looks at me askew / To our Ann who's so stuckup / I'll offer a beer. // And that beer, good beer / Is made from hop / And to make us all cheerful / We have added yeast.

Similarly, the influence of the Polish language is also present in Latvian humorous folk songs (Klavinska 2015a: 271), for instance, in the following folk song recorded in Latgale:

Kristamāmen, dzjadzulin [Ltg 'godmother, aunt'],

Kai [Ltg 'how'] pa polsku [Pl 'in Polish'] havaric [Bel 'to speak']!

Čuda čuda, dzīva dzīva [Pl cudo, dziwo 'miracle']

Ja pa polsku [Pl 'I in Polish'] havarila [Bel 'spoke']:

Sivyi kon, jasna griva [Pl 'grey horse, light mane'],

Pakausteiti kumelini [Ltg 'shod colts'].

(LTDz XI: 56050) 
Due to long-term linguistic contacts, the Latvian language also contains many barbarisms borrowed from the German language, which also reflect in folklore: Visi mani bērninni vāciski mācēja: / Maizìte brotīte, karotīte lepelīte 'All my children could speak German: / Bread brotite (from German Brot 'bread'), spoon lepelīte (from German Löffel 'spoon')' (LTDz I: 2207).

A person's vague mumbling or unintelligible speech is often compared to a German's speech in both Lithuanian and Latvian folklore: Lt "Speaks like a German, it's not possible to understand anything" (LKZ: 913); Lv "Tattles as an osier German" (LSDF 556 6537). Latvian paroemias also depict the garrulity of Lithuanians: "Tattles as a fairy-tale Lithuanian" (LSDF 116 12415).

\section{Perceptive field}

Lithuanian and Latvian folklore make only minor references to the foreigners' appearance (their clothing and physical traits); they are usually not described in detail and are mentioned only as secondary attributes of 'otherness'.

Lithuanian belief legends and tales of the stupid devil often depict the devil as a German gentleman, who stands out among others because of his clothes. In some folk narratives, the devil can even be directly labelled as vokietis 'German', usually in the diminutive form vokietukas: he walks dressed in German clothes, wearing a hat, and leaning on a walking stick. According to researchers of Lithuanian folklore, such stigmatization of German people derives from historical experience, namely, the hatred towards German crusaders (Vèlius 1986: 20). The image of the devil in depicting Germans is also frequent in Polish, Latvian, and Estonian folklore. However, as pointed out by Lithuanian researcher J. Balys, ancient Prussians imagined the devil as a Pole (Balys 1938a: 511). In a similar way, Slavs often depict the devil, a water spirit, and a forest spirit as a German, a Frenchman, or a Jew, and sometimes as a Lithuanian (Tolstoi 1999: 416). Not only in the perceptive field, but also in religious, cultural, social, and linguistic fields, characteristics of the devil (evil spirit) are often attributed to foreigners, followers of other religions, or representatives of other social layers that stand out for their particular traits.

Lithuanian folklore underscores not only German people's different clothing, i.e., lordly and urban clothes as opposed to peasant wear, but also their physical appearance as can be seen, for example, in the saying 'Wheezes as a Prussian soldier' (Jucevičius 1959: XXVI), which is used to describe an obese person. The figure of the German is also frequent in riddle formulas: "A short blunt German dressed in a bony coat / dressed in seven shirts" (the answer 
is a nut / an onion) (LKZ 914). A fat, round object coded in the riddle is often described as an obese and big-bellied German man.

In Latvian folklore, the image of the German is contradictory. Folk songs mention items of clothing that are identified as German and are described as beautiful, for instance, a velvet suit, silk trousers, a sailor's cap (LTDz X: 52914). Moreover, in one text Germans are acknowledged as trendsetters: "Hair cut the German way" (LFK 1940, 7524).

On the one hand, such examples emphasize the social and material superiority of Germans over Latvians. On the other hand, just like in Lithuanian folklore, Germans are compared to the devil, typically when referring to their appearance: "Hey, German, child of the devil, / Boots made by the devil!" (LTDz $\mathrm{X}$ : 52520). The description of the German body shape is also contradictory: sometimes it is depicted as slim, but sometimes as a fat or corpulent figure; slim legs (DS 28266-4), long hair (DS 31893-0), a long, crooked nose (LTDz X: 31852) are mentioned as well.

Descriptions of the appearance of Poles in Latvian folklore usually mention certain items of clothing (attesting to their social and material status), which distinguish a Pole from a Latvian: a black suit, a blue overcoat, a penny-bun shaped hat (LTDz X: 52896, 357). Lithuanian folklore, in contrast, does not make any reference to the appearance of Poles.

The appearance of Lithuanians is rarely given attention to in Latvian folklore. For example, in a riddle where the lexeme designating Lithuanians, $l i$ tauneica, stands for 'reed', this is possibly due to some free associations with their appearance (slim, tall, silk ribbons in the hair) (Uḷanovska 2011: 218). No examples of Lithuanian folk texts that mention the appearance of Latvians were found during this research.

It may be observed that both Lithuanian and Latvian folklore quite rarely refer to the appearance of Germans, Poles or Lithuanians/Latvians because their physical traits are quite similar. In most cases only different clothing is accentuated, stating that the person of another nationality wears fancier 'lordly' clothes, i.e., has a higher status in society.

\section{The field of emotional and intellectual evaluation}

As a rule, folklore portrays desires, goals, and wishes of 'a humble person', typically, a peasant, who then judges certain features and personality traits to be positive or negative. For this reason, folklore texts often reflect the opposition between the poor/peasant and the rich/landowner. 
Lithuanians and Latvians viewed pride, pretentiousness, and boasting (usually attributed to the Polish szlachta or landlords) as negative features; this is also reflected in folklore. Lithuanian paroemias describe Poles as boasters: "Boasts himself as a Pole" (LTR 30/322), or liars: "The truth of the Pole is ridden by the devil in the marsh" (LTR 1854/5/1). Poles are also said to be difficult to get on well with: "You will not be able to get along with the Pole" (LTR 200/56). In the Lithuanian language, Poles' pride or arrogance is given a specific name, 'polskas honoras' (Pl polskie honor, 'Polish arrogance'). The latter saying is still well-known and used in contemporary Lithuania.

By analogy, many Latvian folk texts also mock unlikable Polish character traits, such as bragging, arrogance, and stinginess; this can be seen in such sayings as "bragging as a Polish nobleman" (LSDF 477 306); "a rich, but very stingy Polish nobleman" (Trūps 1968: 128). Poles' reluctance to work is ridiculed as well: "When Latvians were ploughing land, / The Pole was shaking his trousers, / When Latvians were eating bread, / The Pole was smacking his lips" (LFK 828, 18241).

Lithuanian paroemias also mock the Polish language because of its peculiarities. For example, Poles, both in the past and nowadays, tend to address each other as pan, pani (Pl), i.e., 'Sir,' 'Madam'; Lithuanians consider this to be excessive politeness, as is obvious from sayings such as "The Pole calls even a dog a sir" (LTR 209/49/189); "Don't be politer than a Pole" (LTR 4102/124).

Lithuanian folk songs that were created during the interwar period and recount the loss of Vilnius and its liberation, often mention the "sly Pole, a wicked neighbour" (Ivanauskaitè 2004: 41-42).

Lithuanian proverbs also maintain the pattern of calling Germans fools: "Foolish as a German" (Lebedys 1958: 573); "Stupid as a Prussian after lunch" (LTR 2199/31/32); "Would a German understand it the way a Lithuanian does" (Lebedys 1958: 595). Only a few proverbs mention good traits of Germans: "Tidy as a German" (LTR 390/140/412) or "Fair as a German" (LTR 390/140/574). The ability of Germans to manage their property is reflected in the following proverbs: "The German lives better on the stone than the Russian on the black soil and water" (LKZ 1976: 913); "The Pole makes shit from wax, whereas the German makes wax from shit" (LTR 4733/137/2).

In Latvian folklore, the image of the German is contradictory. On the one hand, the German is represented as a fool, as can be seen in the tale in which a witty Latvian farmer outwits gullible Germans (Uḷanovska 2011: 283-290)). A German person's stupidity sometimes manifests in his inability to manage a farm: "A German has as much intelligence / As a little child: / Yesterday he sowed peas in the cornfield, / Today he is going to see / If they have grown big, / If they have started flowering" (LTDz X: 52909). On the other hand, Germans 
may also be depicted as smart people because it is from them that Latvians sometimes seek advice (LTDz X: 52800).

Lithuanian paroemias can also be critical of Latvians: "He has as little shame as a Latvian" (LTR 64/408); "He taught honesty as a Latvian to his children" (TZ 1928: 624).

In popular Latvian sayings, Lithuanians are depicted as fools: "Thick as a Lithuanian" (LSDF 1268 490).

In paroemias, two nations are often compared. The meaning of such paroemias, and their positive or negative connotations depend on the context. Moreover, the same saying can often be used both in its direct and figurative sense: Lt "Made a bargain as a Latvian with a Jew" (LTR 3116/581), Lt "The Latvian is honest before lunch, whereas the German is honest after lunch" (LTR 4883/649), Lt "He oppresses one as a Latvian oppresses a Lithuanian" (LTR 3116/581); Lv "Arguing as a Lithuanian does with a Pole" (LSDF 1552 343); Lv "The German has as much honour as the Gypsy has work" (LSDF 1808 81).

\section{CONCLUSIONS}

Lithuanians' and Latvians' relationships with and attitudes towards foreigners were influenced by historical, political, economic, cultural, religious, social, and psychological factors. Folklore is a reflection of real life and, at the same time, of culture, mentality, the way of living, and values of a specific society. Both in reality and in folklore, a foreigner as well as any other person or phenomenon tends to be stereotyped. Folklore has its own ways to transform reality and uses its own stylistic devices. A stranger is seen within a predetermined frame. Instead of individualising, folklore portrays types, not characters. When creating a type, two or three similar features are brought to the foreground, resulting in an oversimplified image of a stranger.

Contextual semantics of ethnonyms designating foreigners reveals a clear dichotomy between the positively marked our own and the often negatively marked strange. Negative attitude is demonstrated by emphasizing certain traits of strangers, such as speaking a different language, belonging to a different region, social class, culture (traditions), or being marked by a different temperament.

Folklore texts, informed by historical experience of dealing with foreigners, show that ethnonyms are open to semantic transformation in time and space. For instance, in Latvian folklore, the formulaic repetition of the ethnonyms poli, poli $i$, leiši leiši 'Poles, Poles, Lithuanians Lithuanians' is used to refer to 'foreigners, foreign conquerors' in general, the formula dating back to when the territory 
of Latgale was part of the Polish-Lithuanian State. In Lithuanian folklore, the ethnonym Prussian has a generalized meaning of 'the other, strange' and emphasizes belonging to a different geographical location, nation, and religion.

Because of similar historical and social conditions, Lithuanian and Latvian folklore portrays Germans and Poles in a similar manner. In real life, they often had a higher status, and thus in folklore, they also are depicted as masters or landowners and their negative character traits are revealed quite distinctly. Folklore texts of different genres often portray local peasants' encounters with Germans and Poles, during which the foreigners are usually depicted as losers and stupid people, whose conduct is improper, and who are depreciated, mocked, and even humiliated.

Although they are neighbouring nations, Lithuanians and Latvians are portrayed rather rarely in each other's folklore. In earlier (seventeenth-eighteenthcentury) Latvian folklore, the ethnonym Lithuanians is often used to mean 'conquerors', whereas more recent nineteenth-twentieth-century folklore often describes similar everyday realities of the neighbouring nations, especially in the border regions, and thus mostly depicts minor confessional and cultural (traditions-related) differences. In Lithuanian folklore, the image of the Latvian as a sorcerer is quite common. Many short humorous folklore texts are based on wordplay and focus on minor differences between the lexis of the two Baltic languages.

Variants of the same folklore narrative may depict different foreigners. For instance, both the Pole and the German may be addressed as 'sir', or a person of any different nationality may be called 'stupid' if they behave in an unusual manner, even though different models of behaviour are influenced by confessional and social contexts as well as different customs and traditions. The usage of a particular ethnonym depends on what foreigners the local peasants met in their close environment.

\section{ARHIVAL SOURCES}

LFK = Archives of Latvian Folklore, Institute of Literature, Folklore and Art, University of Latvia

LTR = Archive of Lithuanian Folklore, Institute of Lithuanian Literature and Folklore VDU = Archive of the Department of Cultural Studies, Vytautas Magnus University, Kaunas 


\section{NOTES}

1 Until the beginning of the twentieth century, people in Lithuania and eastern Latvia generally assumed that Catholicism was a Polish faith. For instance, during the census of 1897 in tsarist Russia, Catholic Lithuanians, Latvians, and Byelorussians were often registered as Poles, because when census recorders asked them who they were, the latter would answer: "Catholics".

2 Exoethnonym is a name given to an ethnos by other ethnic groups, most frequently by the neighbouring ones.

\section{REFERENCES}

Anglickienè, Laima 2006. Kitataučiu juaizdis lietuviu folklore. [The Image of Foreigners in Lithuanian Folklore.] Kaunas: Versus Aureus.

Anglickienè, Laima 2011. Lenko įvaizdžio pokyčiai XIX a. - XXI a. pradžios lietuvių folklore. [The Changes of the Image of the Pole in the 19th-21st c. Lithuanian Folklore.] In: J. Niewulis-Grablunas \& J. Prusinowska \& E. StryczyńskaHodyl (eds.) Perspectives of Baltic Philology II. Poznań: Rys wydawnictwo, pp. 7-17. Available at https://etalpykla.lituanistikadb.lt/fedora/objects/LT-LDB0001:J.04 2011 1588704715470/datastreams/DS.002.0.01.ARTIC/content, last accessed on 20 September 2021.

Apine, Ilga \& Dribins, Leo 1998. Mazākumtautību vēsture Latvijā. [History of Minorities in Latvia.] Rīga: Zvaigzne ABC.

Balys, Jonas 1938a. Aštrioji tautosaka. [Sharp Folklore.] Jaunoji Lietuva, No. 10, pp. 509-517.

Balys, Jonas (ed.) 1938b. Vilniaus krašto lietuviu tautosaka. [Lithuanian Folklore of the Vilnius Region.] Tautosakos darbai [Folklore Studies], Vol. 4. Kaunas: Lietuviu tautosakos archyvas.

Balys, Jonas (ed.) 1940. Lietuviu liaudies sakmès. [Lithuanian Folk Legends.] Vol. 1. Kaunas: A.S. lituanistikos instituto Lietuvių tautosakos archyvas.

Bartmiński, Jerzy \& Zinken, Jörg (ed.) 2009. Aspects of Cognitive Ethnolinguistics. Transl. by Adam Glaz. London \& Oakville: Equinox Publishing Ltd.

Basanavičius, Jonas 1928 [1903]. Iš gyvenimo vèliu ir velnių. [From the Life of Devils and Souls.] Kaunas: M. Jolko Spaustuvèje.

Berezovich, Elena \& Gulik, Dmitri 2002. Homo ethnicus v zerkale iazyka: k metodike opisaniia. [Homo ethnicos in the Mirror of Language: Towards a Methodology of Description.] Etnolingwistyka: Problemy języka i kultury, Vol. 14, pp. 47-69. Available at http://dlibra.umcs.lublin.pl/dlibra/docmetadata?id=1485\&from=pu blication, last accessed on 21 September 2021.

Boldāne, Ilze 2011. Etnisko stereotipu veidošanās apstāklı Latvijāa: 1850.-2004. [Conditions for the Formation of Ethnic Stereotypes in Latvia: 1850-2004.] Diss. (PhD Thesis). Rīga: Latvijas Universitāte. Available at: https://dspace.lu.lv/ dspace/bitstream/handle/7/4780/29220-Ilze_Boldane_2011.pdf?sequence=1, last accessed on 21 September 2021. 
Butkus, Alvydas 1995. Latviai. [Latvians.] Kaunas: AESTI.

Central Statistics = Centrālās statistikas pārvaldes datubāze. [Central Statistical Bureau Database.] Available at http://www.csb.gov.lv/dati/statistikas-datubazes-28270. html, last accessed on 21 September 2021.

Daukantas, Simonas 1983. Žemaičiu tautosaka. [Samogitian Folklore.] Vol. 1. Vilnius: Vaga.

Dribins, Leo (ed.) 2007. Mazākumtautības Latvijā: Vēsture un tagadne. [Minorities in Latvia: History and the Present.] Rīga: Latvijas Universitātes Filozofijas un socioloğijas institūts.

DS = Krišjāna Barona Dainu skapis. [The Cabinet of Folk Songs by Krišjānis Barons.] Available at http://www.dainuskapis.lv/, last accessed on 21 September 2021.

Durejko, Agṇeška 1995. Daugava poḷu literatūras tradīcijās. [Daugava in the Polish Literary Tradition.] In: Jaroslavs Sozan̦skis (ed.) Latvija-Polija: Starptautiskās zinātniskās konferences "Poḷ un latviešu tautas politiskie, ekonomiskie un kultūras sakari no 16. gs. lìdz 1940. gadam" materiāli. [Latvia-Poland: Proceedings of the International Scientific Conference "Political, Economic and Cultural Relations of the Polish and Latvian People from the 16th Century until 1940".] Rīga: Polijas republikas vēstniecība, pp. 124-132.

Eriksen, Thomas Hylland 2001 [1995]. Small Places, Large Issues: An Introduction to Social and Cultural Anthropology. 2nd ed. London: Pluto Press.

Geeraerts, Dirk \& Cuyckens, Hubert 2007. Introducing Cognitive Linguistics. In: D. Geeraerts \& H. Cuyckens (eds.) The Oxford Handbook of Cognitive Linguistics. Oxford: Oxford University Press, pp. 3-21. DOI: 10.1093/ oxfordhb/9780199738632.013.0001.

Grabis, Rūdolfs (ed.) 1987. Latviešu literārās valodas vārdnīca. [Latvian Literary Language Dictionary.] Vol. 6, part 2. Rīga: Zinātne.

Holbek, Bengt, 1996. Stories about Strangers. In: Leander Petzoldt (ed.) Folk Narrative and World View. Vorträge des 10th Kongresses der Internationalen Gesellschaft für Volkserzählungsforschung (ISFNR). Innsbruck 1992. Teil 1. Beiträge zur Europäischen Ethnologie und Folklore: Tagungsberichte und Materialien. Vol. 7. Frankfurt am Main: Peter Lang, pp. 303-311.

Ivanauskaitè, Vita 2004. Tarpukario Lietuvos dainos: kolektyvinès ir individualios kūrybos sintezè. [Lithuanian Interwar Songs: Synthesis of Collective and Individual Creativity.] In: Vita Ivanauskaitė \& Aušra Žičkienè (comps.) Lietuviu liaudies dainynas: Karinès-istorinès dainos. [Collection of Lithuanian Folk Songs: Military-historical Songs.] Vol. 18, No. 4. Vilnius: Lietuvių literatūros ir tautosakos institutas, pp. 7-50.

Ivanauskaitè, Vita \& Gudaitè, Jūratè (comps.) 1998. Nepriklausomybès kovų dainos. [Songs of the Struggle for Independence.] Vilnius: Lietuvių literatūros ir tautosakos institutas.

Ivanauskaitè, Vita \& Žičkienè, Aušra (comps.) 2004. Lietuviu liaudies dainynas: Karinèsistorines dainos. [Collection of Lithuanian Folk Songs: Military-historical Songs.] Vol. 18, book 4. Vilnius: LLTI.

Janonis, Julius \& Janonienè, Marija (comps.) 1982. Biržu krašto tautosaka. [Folklore of Biržai Region.] Vilnius: Vaga. 
Jokimaitienè, Pranė \& Žičkienè, Aušra (comps.) 1995. Lietuvių liaudies dainynas: Karinès-istorinès dainos. [Collection of Lithuanian Folk Songs: Military-historical Songs.] Vol. 9, book 2. Vilnius: LLTI.

Jucevičius, Liudvikas Adomas 1959. Raštai. [Selected Works.] Vilnius: Valstybinè grožinès literatūros leidykla.

Juška, Antanas (comp.) 1954. Lietuviškos dainos. [Lithuanian Songs.] Vol. 2. Vilnius: Valstybinè grožinès literatūros leidykla.

Karulis, Konstantīns 2001 [1992]. Latviešu etimoloǵijas vārdnīca. [Latvian Etymological Dictionary.] Rīga: Avots.

Kiliánová, Gabriela 1994. Die Reflexion von ethnischen Stereotypen im alltäglichen Erzählen. In: Gabriela Kiliánová \& Eva Krekovičová (eds.) Folklore in the Identification Process of Society. Bratislava: Ústav etnológie SAV, pp. 107-113.

Klavinska, Antra 2015a. The Codes of Various Languages in the Texts of Latgalian Folk Songs. Acta Humanitarica Universitatis Saulensis, Vol. 21, pp. 270-277.

Kḷavinska, Antra 2015b. Etnonīmi latgaliešu folklorā: lingvistiskais aspekts. [Ethnonyms in Latgalian Folklore: The Linguistic Aspect.] Diss. (PhD Thesis). University of Latvia. Available at: http://dspace.lu.lv/dspace/bitstream/handle/7/31016/29851022-Klavinska_Antra_ak05177.pdf?sequence=1, last accessed on 21 September 2021.

Lebedys, Jurgis (ed.) 1958. Smulkioji lietuviu tautosaka XVII - XVIII a.: Priežodžiai, patarles, misles. [Minor Forms of Folklore in the 17th-18th cc.: Proverbial Phrases, Proverbs, Riddles.] Vilnius: Valstybinè grožinès literatūros leidykla.

LKZ 1976 = Lietuviu kalbos žodynas. [Dictionary of the Lithuanian Language.] Vol. 10. Vilnius: Mintis.

LSDF = Latviešu sakāmvārdu datorfonds. [Electronical Fund of Latvian Proverbs.] Available at http://valoda.ailab.lv/folklora/sakamvardi/, last accessed on 21 September 2021.

LTDz 1952-1956 = Latviešu tautas dziesmas (Chansons populaires lettonnes). [Latvian Folk Songs.] Vol. I-XII. Ed. by Arveds Švābe \& Kārlis Straubergs \& Edīte Hauzenberga-Šturma. Copenhagen: Imanta. Available at https://atviandainas. lib.virginia.edu/index.html\%3Flang=lav\&section=home.html, last accessed on 21 September 2021.

Merlingen, Weriand 1978. Über eine Bedeutungsverzeigung im indogermanischen Lexikon. Indogermanische Forschungen, Vol. 83, pp. 40-106. https://doi. org/10.1515/9783110243253.40.

Mīlenbahs, Kārlis 1932. Latviešu valodas vārdnīca. [Dictionary of the Latvian Language.] Vol. IV. Redig̛̣ējis, papildinājis, turpinājis Jānis Endzelīns. Rīga: Kultūras fonds.

Popova, Zinaida \& Sternin, Iosif 2007. Kognitivnaia lingvistika. [Cognitive Linguistics.] Moscow: AST, Vostok-Zapad.

Population 2013 = Gyventojai pagal tautybę, gimtaja kalba ir tikybą: Lietuvos Respublikos 2011 metu visuotinio gyventoju ir būstu surašymo rezultatai. [Population according to Nationality, Mother Tongue and Religion: General Census Results of Lithuanian Republic Populations and House in 2011.] Available at https://osp. stat.gov.lt/documents/10180/217110/Gyv_kalba_tikyba.pdf/1d9dac9a-3d45-479893f5-941fed00503f, last accessed on 21 September 2021. 
Rozenbergs, Jānis 2005. Tautas un zemes latviešu tautasdziesmās. [People and Lands in Latvian Folk Songs.] Rīga: Zinātne.

Slančiauskas, Matas 1975. Šiaurès Lietuvos sakmès ir anekdotai. [Legends and Anecdotes of North Lithuania.] Edited by Norbertas Vèlius \& Adelè Seselskytè. Vilnius: Vaga.

Slavėnienè, Gražina 1991. Lietuvos protestantai. [Lithuanian Protestants.] Mokslas ir gyvenimas, No. 1, pp. 30-31.

Tolstaia, Svetlana 2006. Postulaty moskovskoi etnolingvistiki. [The Tenets of the Moscow Ethnolinguistic School.] Etnolingwistyka: Problemy języka i kultury, Vol. 18, pp. 7-29. Available at https://www.ceeol.com/search/journal-detail?id=2484, last accessed on 21 September 2021.

Tolstoi, Nikita (ed.) 1999. Slavianskie drevnosti. Etnolingvisticheskii slovar'. [Slavic Antiquities: Ethnolinguistic Dictionary.] Vol. 2. Moscow: Mezhdunarodnye otnosheniia. Available at https://www.twirpx.com/file/3105650/, last accessed on 21 September 2021.

Trūps, Jōṇs (ed.) 1968. Latgal̦u folklora 1: tautas jūki, meikles, parunas. [Latgalian Folklore I: Folk Jokes, Riddles, Proverbs.] Munich: Latgalı izdevnīceiba.

TZ 1928 = Iš prof. V. Krèvès-Mickevičiaus tautosakos rinkinių. [From the Folklore Collections of Prof. V. Krèvè-Mickevičius.] Tauta ir žodis, Vol. 5, pp. 572-632.

Uḷanovska, Stefaneja 2011. Pūḷ Inflantejis latvīši, i seviški Rēzeknis apriņka Viḷānu pogosta: etnografiskys tāluojums. [Latvians from Polish Livonia and Especially from Rēzekne District, Viḷāni Parish: Ethnographic Depiction.] Edited by Aleksejs Andronovs \& Lideja Leikuma. Riga: LU.

Vaitiekus, Severinas (comp.) 1992. Tautinès mažumos Lietuvos Respublikoje (statistika, informacija, dokumentai). [Ethnic Minorities in the Republic of Lithuania (Statistics, Information, Documents).] Vilnius: Valstybinis nacionalinių tyrimuc centras.

Vèlius, Norbertas 1987. Chtoniškasis lietuviu mitologijos pasaulis: Folklorinio velnio analize. [Chthonic World of Lithuanian Mythology: Analysis of Folk Devil.] Vilnius: Vaga.

Zinkevičius, Zigmas 2005. Lietuviu tautos kilmè. [The Origin of the Lithuanian Nation.] Vilnius: Mokslo ir enciklopediju leidybos institutas.

Žemaitienè, Uršulè 1953. Suvalkiečiu vestuvès. [Wedding Customs of Suvalkija.] Edited by Jonas Balys. Cleveland: Ohio.

Laima Anglickienè is Associate Professor and Head of Department of Cultural Studies at Vytautas Magnus University, Kaunas, Lithuania. Her main research areas are contemporary folklore, ethnic stereotypes and ethnic processes in the Baltic region.

laimute.anglickiene@vdu.lt

Antra Klavinska is Senior Research Fellow and Associate Professor at Rezekne Academy of Technologies, Latvia. Her research interests are related to ethnolinguistics, applied linguistics and corpus linguistics.

antra.klavinska@rta.lv 